\title{
Evaluation of the Potential for Fish Passage Through the N Reactor and the Hanford Generating Project Discharges
}

D. D. Dauble

L. W. Vail

D. A. Neitzel

September 1987

Prepared for the U.S. Department of Energy under Contract DE-AC06-76RLO 1830

Pacific Northwest Laboratory Operated for the U.S. Department of Energy by Battelle Memorial Institute 


\section{DISCLAIMER}

This report was prepared as an account of work sponsored by an agency of the United States Government. Neither the United States Governmentnor any agency thereof, nor Battelle Memorial Institute, nor any of their employees, makes any warranty, expressed or implied, or assumes any legal liability or responsibility for the accuracy, completeness, or usefulness of any information, apparatus, product, or process disclosed, or represents that its use would not infringe privately owned rights. Referenceherein to any specific commercial product, process, or service by trade name, trademark, manufacturer, or otherwise, does not necessarily constitute or imply its endorsement, recommendation, or favoring by the United States Government of any agency thereof, or BattelleMemorial Institute. The views and opinions of authors expressed herein do not necessarly state or reflect those of the United States Governmentor any agency thereof, or Battelle Memorial Institute.

\section{PACIFIC NORTHWEST LABORATORY operated by BATTELLEMEMORIAL INSTITUTE for the UNITED STATES DEPARTMENT OF ENERGY under Contract DE-AC06-76RLO 1830}

\begin{tabular}{|c|c|}
\hline \multicolumn{2}{|c|}{ Printed in the United States of America } \\
\hline \multicolumn{2}{|c|}{$\begin{array}{l}\text { Available from } \\
\text { National Technical Information Service }\end{array}$} \\
\hline \multirow{3}{*}{\multicolumn{2}{|c|}{$\begin{array}{c}\text { United States Department of Commerce } \\
5285 \text { Port Royal Road } \\
\text { Springfield, Virginia 22161 }\end{array}$}} \\
\hline & \\
\hline & \\
\hline \multirow{2}{*}{\multicolumn{2}{|c|}{$\begin{array}{l}\text { NTIS Price Codes } \\
\text { Microfiche A01 }\end{array}$}} \\
\hline & \\
\hline \multicolumn{2}{|c|}{ Printed Copy } \\
\hline & Price \\
\hline Pages & Codes \\
\hline 001-025 & $\mathrm{A} 02$ \\
\hline $026-050$ & $\mathrm{~A} 03$ \\
\hline $051-075$ & A04 \\
\hline $076-100$ & A05 \\
\hline $101-125$ & A06 \\
\hline $126-150$ & A07 \\
\hline $151-175$ & A08 \\
\hline $176-200$ & A09 \\
\hline $201-225$ & A010 \\
\hline $226-250$ & A011 \\
\hline $251-275$ & A012 \\
\hline $276-300$ & A013 \\
\hline
\end{tabular}


EVALUATION OF THE POTENTIAL FOR FISH PASSAGE THROUGH THE N REACTOR AND THE HANFORD GENERATING PROJECT DISCHARGES

D. D. Dauble

L. W. Vail

D. A. Neitzel

September 1987

Prepared for the U.S. Department of Energy under Contract DE-AC06-76RLO 1830

Pacific Northwest Laboratory

Richland, Washington 99352 

We considered existing laboratory and field data to evaluate the potential for juvenile downstream-migrating salmonids to encounter both the Hanford Generating Project (HGP) and N Reactor discharges. Three general scenarios were assessed for fish exposure: 1) HGP plume centerline passage followed by N Reactor plume centerline passage, 2) HGP plume centerline passage including intersection with the $\mathrm{N}$ Reactor plume, and 3) noncenterline plume passage through the edge of first the HGP and then the N Reactor plume. It is highly unlikely that a fish would pass through both plume centerlines because of the location of the two discharges and because of river-mixing characteristics near the discharges. For the set of conditions that we evaluated, exposure to elevated temperatures would be of insufficient duration to result in mortalities to fish that might encounter both the HGP and N Reactor plumes. 


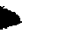




\section{ACKNOMEDGMENTS}

The authors extend their thanks to E. M. Greager of Westinghouse Hanford Company for managing this project. Thanks are also extended to K. A. Borgeson of Pacific Northwest Laboratory for editing this report. This work was funded by Westinghouse Hanford Company, PNL Project No. 11999. 



\section{CONTENTS}

SUMMARY ...................... . . $\ldots$...

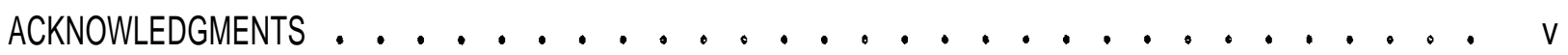

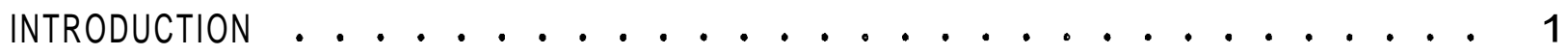
DESCRIPTION OF THE N REACTOR AND HGP DISCHARGES . . . . . . . 3 EVAlUATION OF POTENTIAL PlUME PASSAGE ........... 5

CASE 1: PlUME CENTERLINE PASSAGE ............. 5

CASE 2: HGP PlUME CENTERLINE PASSAGE $\ldots \ldots 6$

CASE 3: PARTIAL DOUBLE PLUME PASSAGE ......... 6

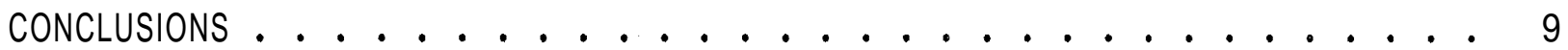

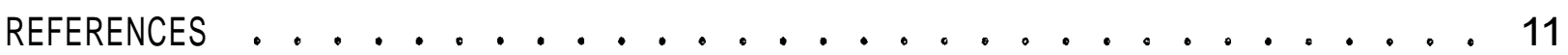


$\because$

-

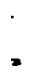




\section{$\underline{\text { INTRODUCTION }}$}

During normal (dual-purpose) operation of $\mathrm{N}$ Reactor, heated water is discharged to the Columbia River through both the N Reactor 009 outfall and the Hanford Generating Project (HGP) discharges. Under these conditions, fish would not be harmed following passage through the N Reactor thermal plume (Neitzel et al. 1984a,b). However, there is concern that the cumulative effects of passage through the HOP plume, followed by passage through the N Reactor plume, could be harmful to downstream-migrating salmonids. This report considered existing laboratory and field data to evaluate the potential for fish passing through both plumes and related possible exposure scenarios to thermal tolerance. We included assumptions of fish avoidance and plume mixing in our assessment. 



\section{DESCRIPTION OF THE N REACTOR AND HCP DISCHARGES}

Water for the heat dissipation system at $\mathrm{N}$ Reactor is discharged to the river through a single midriver discharge port located approximately $400 \mathrm{ft}$ offshore (Figure 1). Heated water is discharged through a 13-ft port that is directed upward. A velocity cap is located $6 \mathrm{ft}$ above the discharge level and acts as a diffuser to divert flows horizontally. The exit velocity of water from the discharge port is about $5 \mathrm{ft} / \mathrm{sec}$.

The HCP discharge is located about $600 \mathrm{ft}$ upstream of the N Reactor discharge and about 300 ' $\mathrm{ft}$ toward the center of the river (Figure 1). The HCP discharge is composed of a multiport diffuser system designed to uniformly distribute the cooling water flow and maximize mixing in the lower one-third depth zone of the river (Raymond Kaiser Engineers 1982).

Measurements taken to characterize the $\mathrm{N}$ Reactor thermal discharge (Ecker, Walters and Thompson 1983) indicated that the HGP thermal plume did not interact directly with the heated water discharged from $N$ Reactor within its National Pollutant Discharge Elimination System (NPDES) mixing zone. The HCP plume centerline occurs about $300 \mathrm{ft}$ from the $\mathrm{N}$ Reactor discharge port and does not extend to within $50 \mathrm{ft}$ of the projected centerline of the $\mathrm{N}$ Reactor thermal plume at points downstream. The plumes begin to merge at about 500 to $1350 \mathrm{ft}$ downstream of the $\mathrm{N}$ Reactor discharge port at river flows of $53,500 \mathrm{cfs}$. Peak temperatures of the HCP and $\mathrm{N}$ Reactor plumes were $2.1^{\circ} \mathrm{F}$ and $1.1^{\circ} \mathrm{F}$ above ambient, respectively, at this point. The two plumes completely merge by $3400 \mathrm{ft}$ downstream of the $\mathrm{N}$ Reactor discharge port, where the combined plume width is about $700 \mathrm{ft}$ and peak temperatures are about $1.8^{\circ} \mathrm{F}$ above ambient (Ecker, Walters and Thompson 1983). 


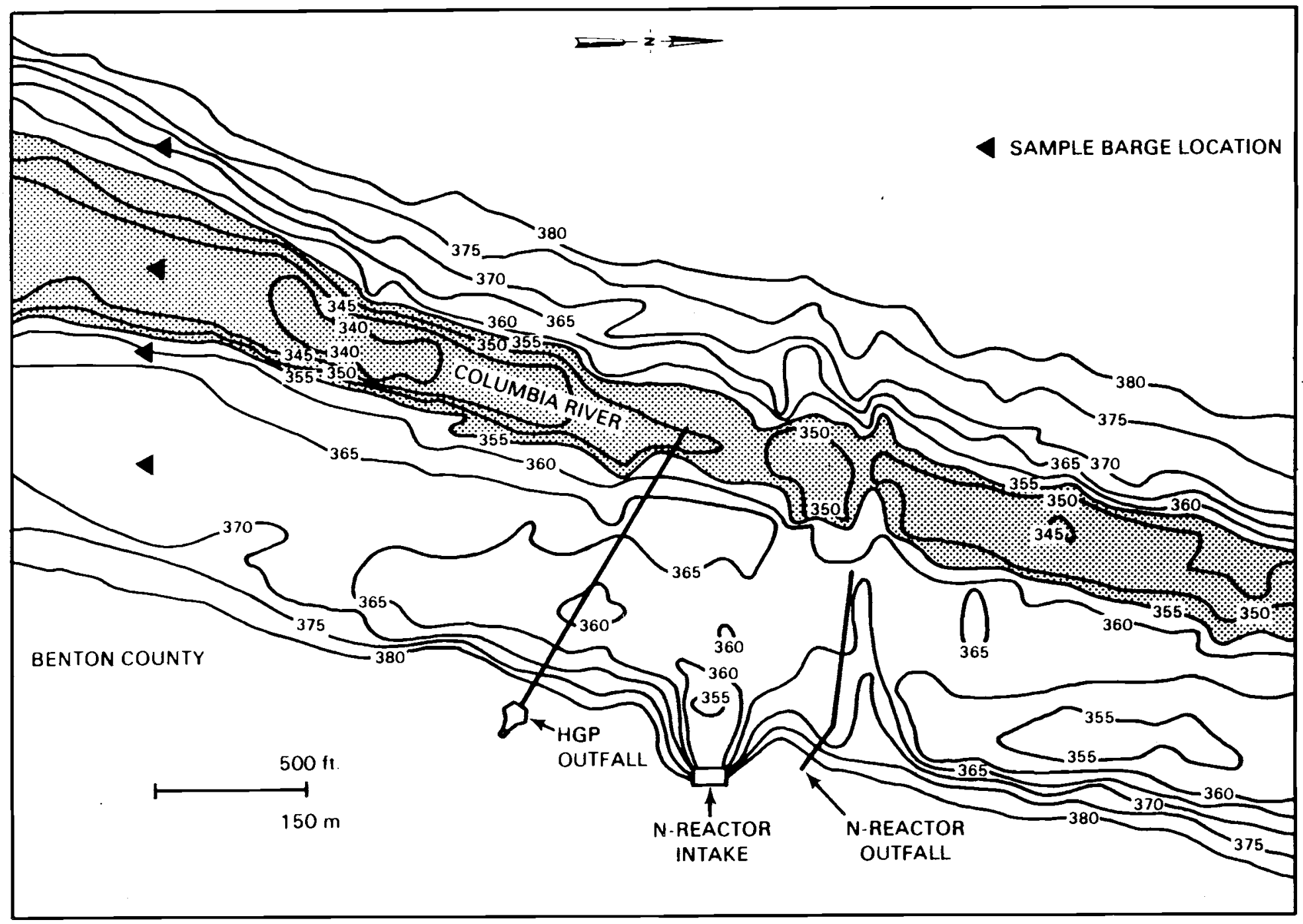

FIGURE 1. Location of $N$ Reactor and HGP Thermal Discharge Outfalls in the Columbia River. Stippled Area Denotes the River Thalweg 


\section{EVALUATION OF POTENTIAL PLUME PASSAGE}

Three genera1 scenarios were developed for fish exposures to the plumes. These scenarios include fish passage through both the HCP and N Reactor thermal plumes: 1) HCP plume centerline passage followed by $N$ Reactor plume centerline passage, 2) HCP plume centerline passage including intersection with the $\mathrm{N}$ Reactor plume, and 3) noncenterline plume passage first through the edge of the HCP plume and then through the edge of the $\mathrm{N}$ Reactor plume. The potential for occurrence for these three scenarios and our assessment is discussed below.

\section{CASE 1: PLUME CENTERLINE PASSAGE}

It is unlikely that a fish could swim through both the HCP and N Reactor plume centerlines because of the mixing characteristics of the thermal plumes and the distance between the two discharges. First, maximum exposure temperatures during plume passage would be less than those predicted from discharge temperatures. This assumption is supported by field measurements of the HCP and N Reactor discharges (Larsen 1985; Ecker, Walters and Thompson 1983). In addition, a downstream-moving fish could not be entrained in the thermal plume until the plume had mixed with ambient river water. Velocity differences between the discharged heated water and the river would prevent a fish from becoming entrained (i.e., a fish could not swim into the discharge port). To remain at maximum thermal exposure levels, a fish would have to enter and remain in the HCP plume centerline as mixing occurs and as the plume rises to the surface. Subsequent exposure to the N Reactor plume centerline would be possible only if the fish then voluntarily swam from its midchannel migration route, angled $300 \mathrm{ft}$ toward the Benton County shoreline, altered its swimming depth to encounter the $\mathrm{N}$ Reactor discharge port, and then remained in the plume centerline untit complete mixing occurred. This entire sequence of events would have to be realized before double-plume centerline passage could occur.

There is no basis for assuming that such a sequence of events would occur. A fish that encountered the HCP plume centerline could not conceivably 
alter its migration route to encounter the N Reactor plume centerline. Because of the improbability of such a sequence of events, potential thermal exposures were not assessed.

\section{CASE 2: HGP PLUME CENIERUNE PASSACE}

The effect of the HGP plume centerline passage on juvenile salmonids could be assessed using methods previously applied to the $\mathrm{N}$ Reactor thermal plume assessment (Neitzel et a1. 1984a,b) . For example, the RBJ-3 model was previously applied to the HGP discharge to provide predicted time-temperature relationships at the plume centerline (WPPSS 1978). However, this model presented conservative predictions (i.e., higher temperatures than actual) in the near field and was not considered applicable for predicting thermal regimes beyond $210 \mathrm{ft}$ downstream of the HGP discharge. In addition, a multiport diffusor system was installed at the HGP discharge in 1983, which altered the characteristics of the HGP thermal plume. Limited field studies were undertaken to document the performance of the diffuser system (Larsen 1985), but surveys were not detailed enough to provide model calibration for input to a double-plume centerline assessment. Studies conducted for N Reactor plume passage (Neitzel et al. 1984a,b) are not applicable because these studies considered a single-plume passage scenario.

Field and modeling studies of the $\mathrm{N}$ Reactor plume (Ecker, Walters and Thompson 1983) indicate that maximum $\Delta T$ s where the HGP and N Reactor plumes intersect will be about $2^{\circ} \mathrm{F}$. This incremental temperature increase would not be lethal to juvenile salmonids that pass through the plume centerline at the HGP.

\section{CASE 3: PARTIAL DOUBLE PLUME PASSAGE}

The maximum combined widths of the HGP and N Reactor thermal plumes encompass about $40 \%$ of the river $\left(22^{\circ} \mathrm{F}\right.$ isotherm) when they combine downstream of the $N$ Reactor discharge. Therefore, it is likely that downstream-migrating salmonids will encounter some portion of either or both thermal plumes. Fish are unlikely to encounter peak temperatures associated with both HGP and $\mathrm{N}$ Reactor operations because of the size of the river and the distance between 
the two discharges. For example, Ecker, Walters and Thompson (1983) reported that $\Delta T$ s greater than $4^{\circ} \mathrm{F}$ were limited to the area within $50 \mathrm{ft}$ of the $\mathrm{N}$ Reactor discharge at river flows of 53,500 cfs. Preliminary studies of the HCP discharge also indicate that rapid mixing causes the warmest temperatures discharged to be quickly reduced (Larsen 1985).

Exposure of juvenile salmonids to peak temperatures in either the HCP or $\mathrm{N}$ Reactor thermal plumes is unlikely because these fish are able to avoid lethal temperatures. Studies indicate that given a choice, juvenile salmonids will avoid $\Delta T$ s that exceed their preferred temperature range. For example, Gray et al. (1977) found that 0 -age chinook salmon avoided plume temperatures greater than $16^{\circ} \mathrm{F}$ above ambient in current velocities of $2 \mathrm{ft} / \mathrm{sec}$. Fish exposed to temperatures above $77^{\circ} \mathrm{F}$ exhibited spasmodic contractions but were capable of escaping the temperature, and none died.

A fish that detected and avoided the HCP thermal plume and then moved into the edge of the $\mathrm{N}$ Reactor thermal plume could encounter elevated temperatures at low $\Delta T$ s. If the downstream extent of both the HCP and $N$ Reactor thermal plumes is considered, total plume passage time for a passively drifting fish encountering $\Delta T$ s greater than or equal to $2^{\circ} \mathrm{F}$ would be about $30 \mathrm{~min}$ $(4000 \mathrm{ft}$ at $2 \mathrm{ft} / \mathrm{sec})$. This exposure duration is not lethal to juvenile salmonids that encounter these low incremental temperature increases (Neitzel et al. 1984a,b; Brett 1952). 



\section{CONCLUSIONS}

It is unlikely that juvenile salmonids will encounter lethal temperatures as a result of passing through the HGP and $\mathbf{N}$ Reactor plumes. Fish passage through the $\mathbf{N}$ Reactor thermal plume under normal operating conditions will result in 100\% survival of the fish. Fish passage through both the HGP and N Reactor plume centerlines is unlikely because of the flow characteristics of the thermal plumes and the location of the two discharges. Downstreammigrating salmonids could encounter elevated temperatures because of the merging of the HGP and N Reactor thermal plumes, but exposure duration is too brief and temperatures too low to result in mortality. Avoidance behavior is expected to further reduce the potential for fish to encounter lethal thermal conditions. 



\section{REFERENCES}

Brett, J. R. 1952. "Temperature Tolerance in Young Pacific Salmon, Genus Oncorhynchus. " J. Fish. Res. Bd. Canada. 9:265-323.

Ecker, R. M., W. H. Walters, and F. L. Thompson. 1983. N Reactor Thermal Plume Characterization Study During Dual-Purpose Mode of Operation. Part 1.-Field Investigation, Part 11.-Computer Simulation. Prepared for UNC Nuclear Industries, Inc. by Pacific Northwest Laboratories, Richland, Washington.

Gray, R. H., R. G. Genoway, and S. A. Barraclough. 1977. "Behavior of Juvenile Chinook Salmon, Oncorhynchus tshawytscha, in Relation to Simulated Thermal Effluent." Trans. Am. tish. Soc. 106(4):366-370.

Larsen, J. 1985. Hydrothermal Field Study of Cooling Water Diffuser Outfall Hanford Generating Station. 1-85/M456F. Alden Research Laboratory, Holden, Massachusetts.

Neitzel, D. A., T. M. Poston, C. S. Abernethy, T. L. Page, and D. W. Carlile. 1984a. Laboratory Simulation of Late-Summer Juvenile Chinook Salmon Passage Through $N$ Reactor Thermal Plume During Sing1e-Purpose Mode of Operation. UN1-2755. Prepared by Pacific Northwest Laboratory, Richland, Washington for UNC Nuclear Industries, Inc.

Neitzel, D. A., T. M. Poston, C. S. Abernethy, M. T. McLane, T. L. Page, and D. W. Carlile. 1984b. Laboratory Simulated Passage of Four Species of Fish Through the N Reactor Thermal Plume in Spring During Single-Purpose Mode of Operation. UNI 3220. Prepared by Pacific Northwest Laboratory. Richland, Washington for UNC Nuclear Industries, Inc.

Raymond Kaiser Engineers. 1982. Outfall Diffuser Conceptual Design. Prepared for Washington Public Power Supply System by Raymond Kaiser Engineers, Oakland, California.

Washington Public Power Supply System (WPPSS). 1978. Supplemental Information on the Hanford Generating Project in Support of 316(a) Demonstration. Washington Public Power Supply System, Richland, Washington. 
: 


\section{DISTRIBUTION}

No. of

Copies

OFFSTTE

3 DOE Technical Information Center

ASITE

DOE Richland Operations Office

J. J. Sutey

30 Westinghouse Hanford Company

E. M. Greager
No. of

Copies

19 Pacific Northwest Laboratory

K. A. Borgeson

D. D. Dauble

D. W. Dragnich

R. M. Ecker

M. J. Graham

J. M. Hales

P. C. Hays

D. A. Neitzel

T. L. Page

J.A. Stottlemyre

L. W. Vail

R. E. Wildung

Publishing Coordination (2)

Technical Report Files (5) 


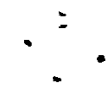

$\bullet$ 